\title{
ADDITIONS TO "BIRDS OF THE ROSETOWN-BIGGAR DISTRICT, SASKATCHEWAN"
}

\section{GUY J. WAPFLE, Box 1153, Biggar, Saskatchewan SOK OM0}

Shortly after the publication of any local bird list, a number of new or unusual birds are bound to turn up in that locality. "Birds of the RosetownBiggar District, Saskatchewan" is no exception and, since its publication in August, 1975, a number of interesting observations have been made in the area.

The following records include data on seven new species noted since 1975. All recent observations of rare or unusual birds are also included in this report. Where a species has five or fewer previous records in the Rosetown-Biggar area this has been mentioned in the species account. "Argo Bush" is 10 miles southwest of Biggar.

The number of species of birds definitely identified in the RosetownBiggar study area now stands at 243 (as of July 9, 1977). In addition, five species remain on the hypothetical list: Western Sandpiper, Blacknecked Stilt, Band-tailed Pigeon, Chimney Swift and Dickcissel. Except where noted, all observations were made by the author.

The author wishes to thank the following people for their help on field trips, bird counts, and observations in the Biggar district: P. de Bussac, R. Chulach, D. Dueker, J. Goring, W. C. Harris, S. M. Lamont, M. L'hoir, A. de Moissac, M. Newton, D. H. and W. E. Renaud and R. A. Wapple. Special thanks to Wayne Renaud or his encouragement and uggestions on this article.

RED-NECKED GREBE. On May 2, 1976, an adult was swimming with everal dozen ducks along the north hore of Middle Van Scoy Lake. There vere only two prior records for the rea.
WESTERN GREBE. A dead adult was found on a peninsula in the sewage lagoon just south of Biggar on June 14, 1976. A single bird at Castlewood Lake on September 12, 1976 is only the second fall record for the district.

WHITE PELICAN. A. L'hoir found a single bird dead in his field southeast of Whiteshore Lake on August 6, 1975: the author and R. A. Wapple verified the identification. Twentytwo pelicans were noted flying north, 6 miles east-southeast of Biggar on April 18, 1976.

TURKEY VULTURE. R. A. Wapple reported an individual soaring south over Biggar on May 14, 1976. This represents the fifth record since 1968.

BROAD-WINGED HAWK. In 1976, this species was seen on May 2 (an adult low over The Van Scoy Lakes) and May 19 (an immature flushed from aspen woods 2 miles south of Duperow).

FERRUGINOUS HAWK. A single bird was soaring high over Biggar on September 6, 1975.

PEREGRINE FALCON. In 1975 this species was recorded on September 18 , an immature in a park in Biggar (as close as 20 feet) and September 27, one flying amongst a flock of 50 Lapland Longspurs, three miles northwest of Feudal. Single birds were pursuing House Sparrows in town on April 11 and 12,1976. Four previous occurrences have been reported.

RING-NECKED PHEASANT. Pheasants appear to have increased in the region recently. Jim Goring reported a male, 6.5 miles west of Biggar in mid-November, 1975. In 1976, a male flushed with eight Sharptailed Grouse, 15 miles south of town on March 12; and another male was seen on the west outskirts of Biggar 
on March 25 (R. A. and G. J. Wapple). Possible local breeding is indicated with the sighting of a male bird crowing in "Argo Bush" on May 26, 1976. This was reported by Murray Newton, who is familiar with this species, having hunted it in the past. Prior to 1975, three sightings had been made by the Renauds in the area.

VIRGINIA RAIL. Single birds were flushed from a sedge and hummock complex at the east end of Castlewood Lake on June 14 and 15, 1976. On June 15, after flushing the adult bird, a search of the immediate area turned up a broken egg. The egg was quite different in appearance from the Sora's (a nest of the latter was discovered on the same date) and I feel that the broken egg was indeed a Virginia Rail's.

WESTERN SANDPIPER. On May 30 , 1977 the writer, R. A. Wapple and R. Chulach studied four Western Sandpipers feeding alone on a mudflat three miles northwest of Catherwood Lake. From distances ranging from 2035 feet, we noted the rusty-brown crown and back, black legs, quite distinct $v$-shaped breast markings and fairly long bill with a noticeable droop at the tip. The birds were studied for 10 minutes before they flew off to the northeast. There is but one previous record locally (on July $25,1974)$, and only one prior provincial record.

*SHORT-BILLED DOWITCHER. The first confirmed record of this species was on September 8, 1975, when W. E. Renaud, R. A. Wapple and the writer studied one on a mudflat, just southwest of Perdue. We were able to approach within 15 feet of the bird. When it flushed, it gave a three-note call and Renaud, who is familiar with the species in Arctic Canada, confirmed the individual as a Short-billed Dowitcher. Two dowitchers were carefully identified on a mudflat four miles southeast of Keppel on May 12, 1976. These birds also gave a threenote call when flushed and were believed by the writer to be this species.

*New species for the district.
^BUFF-BREASTED SANDPIPER.

The first local record was a group of three identified by D. H. Renaud ano G. J. Wapple one mile west of Catherwood Lake on May 22, 1977 The sandpipers allowed a long study from 20-30 feet as they fed in a wet weedy field.

HUDSONIAN GODWIT. One observ. ed at Catherwood Lake by W. E Renaud and G. J. Wapple on September 8, 1975. On July 11, 1976 ; flock of 18 (with 1 Marbled Godwit was found at a small pond, north o Duperow.

BONAPARTE'S GULL. There have been two additional records of thi distinctive bird. In 1975 an adult wa: flying amongst 100 Franklin's Gull south of Biggar on July 17; in 1976, pair of gulls foraged at the sewage lagoon south of town on April 27. Or both occasions the white wing triangle was seen very clearly.

\section{GREAT-CRESTED FLYCATCHER}

An adult was flycatching vigorousl? from dead poplars in a shelterbelt miles north of Duperow or September 6, 1975. The Renauds hac recorded four other dates.

SAY'S PHOEBE. On May 19, 1976 one was noted along a fence line it "Argo Bush".

BLUE JAY. R. A. Wapple found single bird in Biggar on January 3 1976. Another jay was found 15 mile south of town by R. Chulach, R. A and G. J. Wapple on September 26 1976. This individual was associate with a magpie. During the Bigga Christmas Count on December 2 1976, W. C. Harris and S. M. Lamor heard a single Blue Jay in "Arg Bush."

*BOREAL CHICKADEE. On Octobe 16, 1975, R. A. Wapple and the autho observed an individual in coniferol trees in a park in Biggar. From dis tances of 3-10 feet we obtained th following characteristics: rusty side brown cap and back and hoars voice. A direct comparison was mad between this bird and the singl Black-capped Chickadee with whic it was travelling. Both of us are com 
pletely familiar with both species, having observed dozens of them in northern Saskatchewan and the Rocky Mountains. This is the species' first appearance in the RosetownBiggar area.

MOCKINGBIRD. A single bird was recorded on June 13, 1976, 1.5 miles east of Duperow by P. de Bussac, A. de Moissac and the writer; and another in Biggar on June 3 ( $R$. A. Wapple) and June 4 (R. A. and G. J. Wapple), 1977. Both birds were singng quite vigorously and were assumid to be males. These observations epresent the second and third local ightings, the first being on June 268, 1972 .

WOOD THRUSH. On May 27, 1976, . A. and G. J. Wapple studied an dult Wood Thrush in a park in Biggar rom about 15 feet away, making a lew species for the area, and robably the fourth record for askatchewan. In comparing the bird vith a Swainson's Thrush, we found hat it was slightly larger in size, the ack was much rustier, and the breast pots were larger and more umerous. The bird foraged along he ground in a thick shrubline for ome 20 minutes, after which we left he area.

IERMIT THRUSH. This species was oted on October 2, 1974 (1) and in 976 on April 26 (1), September 18 (1), eptember 25 (2), September 26 (4), lock in farmstead, 12 miles outhwest of Biggar), and October 13 ), (R. A. Wapple). Except for the cord on September 25, all obserations were made at the park in iggar.

EASTERN BLUEBIRD. The first osetown-Biggar sighting occurred n September 19, 1975, when I noted male in a roadside ditch in "Argo ush." The rusty-orange breast was en clearly at 15-30 feet. The uebird fed from a telephone line ith a mixed flock of 5 male and 1 male Mountain Bluebirds, 7 Robins, Palm and 10 Yellow-rumped arblers. It left the area, alone, after out 15 minutes of feeding.

OWNSEND'S SOLITAIRE. TWO solitaires were found in the park in Biggar on April 12, 1976. R. A. Wapple observed two more on the late date of May 29, 1977, as close as 5 feet, just northwest of town. There had been only three previous solitaire records.

NASHVILLE WARBLER. On September 3, 1976, I carefully identified one at the park, with the following field marks: small size (no more that 4 inches), greenish upperparts, yellow underparts, lack of wingbars, and white spectacles around the eyes clearly visible. The Nashville was studied for 10 minutes from 15-20 feet. The Renauds had but one previous record, on September 5, 1973.

MAGNOLIA WARBLER. A close check of flocks of Yellow-rumped Warblers has resulted in an increased number of sightings of this species. All observations have been of female or immature birds, and all were in or near Biggar. 1975: September 7 (3 with 15 Myrtles); September 16 (2 with 10 Myrtles); September 17 (2). 1976: September 24 (5). A male was present in town on May 12, 1977.

CAPE MAY WARBLER. From the park in Biggar come these observations: 1975: September 12 (1 pair), and September 17 (a male in full breeding plumage); 1976: September 12 (a single female). It is perhaps interesting to note that all these records came from the same stand of conifers in the park.

\section{* BLACK-THROATED BLUE} WARBLER. On May 17, 1976, R. A. Wapple and the writer studied a female in deciduous trees at the park in Biggar for 45 minutes. From distances of 6-20 feet, the chacteristics were: olive-green back, greenish underparts, distinct white eyeline and the small, white wingspot on the lower primaries (at the base). The warbler was exceedingly tame as she fed in the lower branches of the trees.

BAY-BREASTED WARBLER. A male was seen in the park in town on June 2, 1976 by R. A. Wapple. This was the fourth local record. 
CONNECTICUT WARBLER. We located a pair in our yard in Biggar on September 5, 1975, noting the complete white eye-ring. There is but one prior sighting, one bird on August 22 and 23, 1972.

WESTERN TANAGER. Single males in Biggar seen separately by R. A. and G. J. Wapple on May 31, 1976, were likely the same bird. This provides the third record of this species for Rosetown-Biggar.

RED CROSSBILL. Both this and the next species have increased in the area recently, with all records coming from the park in Biggar where there are many coniferous trees. In 1975, Reds were seen on: October 13 (1), 15 (3) and 29 (6); November 2 (1) and 4 (1). In 1976 they were spotted on: May 13 (a pair); October 23 (3), and November 8 (a pair). Prior to this influx, there had been but two records.

WHITE-WINGED CROSSBILL. Observed in 1975 on November 11 (4), $12(1), 13$ (2), 14 (a pair), and 18 (1). The only record away from Biggar was at a farm southeast of town on December 24, where a male was located by D. H. Renaud and the author during the Biggar Christmas Count. In 1976, sightings were for February 13 (a pair) and 20 (1). Three previous occurrences are listed for the area.

LARK SPARROW. At the park in
Biggar on May 22, 1976, a single bir was singing. A pair of Lark Sparrow was on territory 2.5 miles south town on May 23 and June 19, 197) but we were unable to locate a nes This handsome sparrow was note four times before 1976 .

SWAMP SPARROW. The fourth loce record was registered on May 15 1977, a single bird in long grass at th park in town.

McCOWN'S LONGSPUR. Anothe observation of this species from th southern part of the study area cam on May 23, 1976, where R. Chulach, I A. Wapple and the writer found eigh males and one female in cultivate stubble 2 miles southeast $c$ Rosetown. A displaying male 7 mile north of Rosetown was noted late that same day.

*SMITH'S LONGSPUR. The first di trict observation was on May 15, 197 when at least 125 Smith's were locate (in association with. over 375 Laplan Longspurs) in a ploughed slough bo tom, just south of Leney. Several di tinctive males were seen, along with much higher number of females, giving calls different from th Lapland's.

'RENAUD, W. E., and D. H. RENAUD. 19; Birds of the Rosetown-Biggar Distri Saskatchewan. Spec. Pub. 9., Sask. N Hist. Soc., Regina.

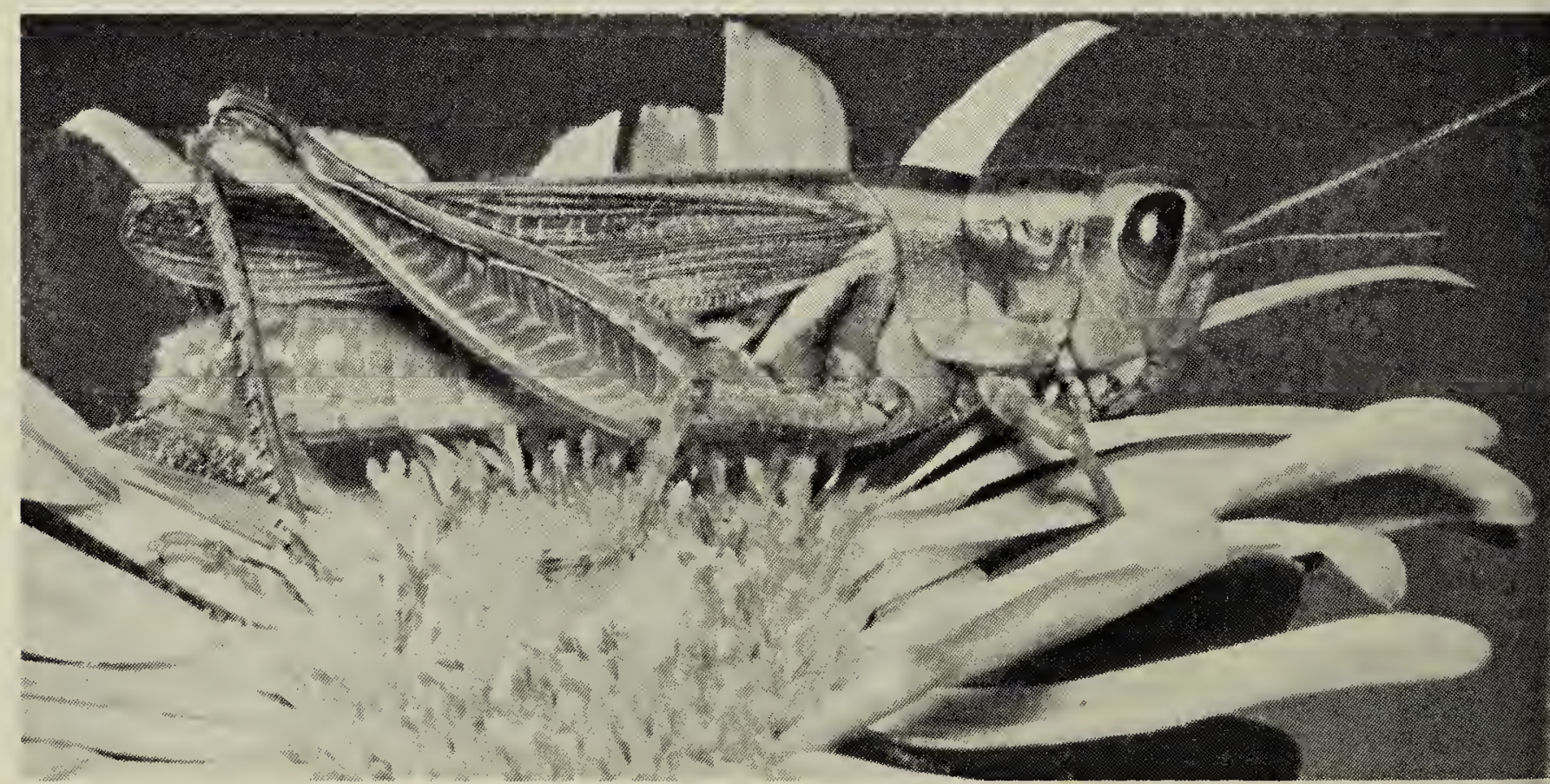

Grasshopper

Hans Domma: 